\title{
Analisis Penggunaan Kohesi Leksikal pada Teks Cerita Pendek Siswa Kelas XI SMA Negeri 4 Bogor
}

\author{
Oleh: \\ Suhendra ${ }^{1}$, Alma Patriani R. ${ }^{2}$, \\ 1, Pendidikan Bahasa dan Sastra Indonesia, FKIP UNPAK, Bogor \\ 2, Pendidikan Bahasa dan Sastra Indonesia, FKIP UNPAK, Bogor
}

\begin{abstract}
This research aims to describe the use of types of lexical cohesion tools in short story texts of eleventh grade SMA Negeri 4 Bogor. The method in this research is descriptive qualitative method. The data collection technique in this research is literature study. The validity checking of the data in this study used triangulation. The source of this research is short story text of eleventh grade SMA Negeri 4 Bogor. The focus of lexical cohesion tool in this research are repetition, synonym, antonym, hyponym, collocation, and equivalence. Based on the results of data analysis found 140 lexical cohesion tools were used. The first number of findings, the use of reps was 36 findings $(26 \%)$. The tool of lexical cohesion was found in repetition of incomplete words in person pronouns, whole words in person pronouns, and whole words in time adverbs. Second, it is synonymous with a total of 14 findings (10\%). In general this cohesion tool was found by looking at the form of language whose meaning is similar or similar to other forms of language. Third, antonym with a total of 24 findings (17\%). This cohesion tool can be identified by looking at words that have different meanings in other words. Fourth, hyponym with a total of 10 findings (7\%). Hyponyms are related to words that have a narrower meaning and are covered in the meaning of one more general word. Fifth, 24 collocations were found (17\%). Collocation, related to the relationship of words and other words in the same environment. Finally, equivalence with a total of 32 findings (23\%). The tool for lexical cohesion in general, deals with the use of meaning that is very close because of the use of the same basic words. Thus, from this number it can be concluded that in the short story students found many uses of lexical cohesion tools from 25 short stories found as many as 140 data findings and the use of the most dominant lexical cohesion tool found in the use of repetition with data findings of $26 \%$ data. Repetition is widely used by students to express affirmation of the object being told. In addition, the cohesion tool is also used with the intention of repetition with the replacement of the word referenced by the word that replaces it.
\end{abstract}

\section{Keywords: Lexical cohesion tools, short stories}

\begin{abstract}
ABSTRAK
Penelitian ini bertujuan untuk mendeskripsikan penggunaan jenis alat kohesi leksikal pada teks cerita pendek siswa kelas XI SMA Negeri 4 Bogor. Metode yang digunakan dalam penelitian ini, yaitu metode kualitatif deskriptif. Teknik pengumpulan data yang digunakan dalam penelitian ini adalah studi pustaka. Pengecekan keabsahan data dalam penelitian ini menggunakan triangulasi. Sumber data penelitian ini teks cerita pendek siswa kelas XI SMA Negeri 4 Bogor. Alat kohesi leksikal yang menjadi fokus penelitian yaitu, repetisi, sinonim, antonim, hiponim, kolokasi, dan ekuivalensi. Berdasarkan hasil analisis data ditemukan penggunaan alat kohesi leksikal sebanyak 140 data. Jumlah temuan yang pertama, penggunaan repetisi sebanyak 36 temuan (26\%). Alat kohesi leksikal tersebut ditemukan pada pengulangan kata tak utuh pada kata ganti orang, kata utuh pada kata ganti orang, dan kata utuh pada kata keterangan waktu. Kedua, sinonim dengan total 14 temuan (10\%). Pada umumnya alat kohesi ini ditemukan dengan mencermati bentuk bahasa yang maknanya mirip atau sama dengan bentuk bahasa lain. Ketiga, antonim dengan total 24 temuan (17\%). Alat kohesi ini dapat diidentifikasi dengan mencermati kata yang berlawanan makna dengan kata lain. Keempat, hiponim dengan total 10 temuan (7\%). Hiponim kaitannya dengan kata yang memiliki makna lebih sempit dan terliput dalam makna dari satu kata yang lebih umum. Kelima, kolokasi sebanyak 24 temuan (17\%). Kolokasi, kaitannya dengan hubungan kata dan kata lain dalam lingkungan yang sama. Terakhir, ekuivalensi dengan total 32 temuan (23\%). Alat kohesi leksikal tersebut pada umumnya, berkenaan dengan penggunaan makna yang sangat berdekatan karena penggunaan kata dasar yang sama. Dengan demikian, dari jumlah tersebut dapat disimpulkan bahwa dalam cerpen siswa ditemukan banyak penggunaan alat kohesi leksikal dari 25 cerpen ditemukan jumlah temuan sebanyak 140 data dan penggunaan alat kohesi leksikal yang paling dominan terdapat pada penggunaan repetisi dengan temuan data 36 data dengan persentase $26 \%$. Repetisi banyak digunakan siswa untuk menyatakan penegasan terhadap objek yang diceritakan. Selain itu, alat kohesi tersebut juga digunakan dengan maksud pengulangan dengan penggantian pada kata yang dirujuk oleh kata yang menggantikannya.
\end{abstract}

Kata kunci: Alat kohesi leksikal, cerita pendek 


\section{PENDAHULUAN}

Dalam pembelajaran bahasa Indonesia, materi keterampilan menulis sudah diberikan sejak pendidikan sekolah dasar hingga perguruan tinggi. Hal tersebut terdapat dalam silabus mata pelajaran bahasa Indonesia terlebih untuk jenjang SMA. Dalam muatan pembelajaran Bahasa Indonesia jenjang SMA/MAN ini termuat lebih dari 20 jenis teks yang dijadikan materi pembelajaran. salah satu teks tersebut adalah teks cerita pendek.

Belajar menulis dapat melatih siswa untuk kreatif mengolah kata dari pengalamannya yang sudah mereka rasakan. Tulisan yang baik akan memberikan kemudahan bagi pembaca dalam memahami maksud atau pesan yang akan disampaikan penulis. Selain itu, suatu teks yang baik adalah teks yang apabila dilihat dari segi hubungan bentuk atau strukturnya bersifat kohesif dan dilihat dari segi hubungan makna atau struktur batinnya bersifat koheren. Teks tersebut dapat dikatakan utuh apabila kalimat-kalimat di dalamnya mendukung satu topik yang sedang dibahas, sedangkan wacana dikatakan baik apabila kalimat-kalimatnya disusun secara teratur dan sistematis, sehingga menunjukkan keruntutan gagasan yang diungkapkan melalui penanda kekohesian.

Aspek yang membentuk kohesi di dalam teks harus jelas dan tepat mendukung koherensi. Apabila urutan paragraf pada suatu teks tidak jelas maka akan menyebabkan ambigu dan tidak koheren. Teks yang tidak jelas urutan awal, tengah, dan akhir bukan merupakan tulisan yang baik. Hubungan kohesi diciptakan atas dasar aspek leksikal dengan pilihan kata yang serasi, begitu pun dengan hubungan makna antar kalimat dengan kalimat yang lain dalam sebuah tulisan, seperti halnya sebuah cerita pendek yang baik harus mempunyai kesatuan, penyatuan dan pengembangan. Kesatuan ditimbulkan oleh kalimat-kalimat yang mendukung pikiran pokok yang ada dalam cerita pendek, sedangkan penyatuan merupakan proses hubungan yang membentuk hubungan yang serasi antar kalimat dalam sebuah cerita pendek. Setelah ada kesatuan dan penyatuan, sebuah cerita pendek perlu dikembangkan dengan pola pengembangan tertentu. Dengan demikian, cerita pendek akan menjadi tulisan yang utuh dan mudah dipahami.

Fokus permasalahan dalam penelitian ini adalah penggunaan jenis kohesi leksikal yang terdapat dalam teks cerita pendek siswa kelas XI SMA Negeri 4 Bogor dan penggunaan jenis kohesi leksikal yang paling dominan digunakan siswa.

\section{LANDASAN TEORI}

\section{Pengertian Kohesi Leksikal}

Menurut Sumarlam (2003:35) Kohesi leksikal adalah hubungan antar unsur dalam wacana secara sistematis. Dalam hal ini, untuk menghasilkan wacana yang padu pembicara atau penulis dapat menempuhnya dengan memilih kata-kata yang sesuai dengan isi kewacanaan yang dimaksud. Hubungan kohesi yang diciptakan atas dasar aspek leksikal, dengan pilihan kata yang serasi, menyatakan hubungan makna atau relasi semantik antar satuan lingual yang satu dengan satuan lingual yang lain dalam wacana.

Keterkaitan makna di dalam suatu wacana dapat dilihat pada segi kosa katanya, hal ini disebut kohesi leksikal. Tekstur yang terdiri dari jalinan kata-kata menjadikan suatu teks padu tanpa mengabaikan konteksnya. Yang berperan di sini adalah konsep semantik. Berkat adanya keterkaitan makna ketidakjelasan satu 
bagian teks dapat ditipang oleh bagian teks yang lain. Kohesi leksikal diperoleh dengan cara memilih kosakata yang serasi.

Menurut Tarigan (2009:98) Aspek leksikal kohesi ini, antara lain; Pengulangan (repetisi), sinonim, antonim, hiponim, kolokasi, dan ekuivalensi. Selanjutnya, Zaenal Arifin dkk. (2015:67) menyatakan bahwa kohesi leksikal menunjukan pada hubungan lesikal di antara bagian-bagian wacana untuk mendapatkan keserasian struktur secara kohesif. Kohesi leksikal terdiri atas sinonim (makna mirip), antonim (lawan kata), hiponim (hubungan bagian atau isi), repetisi (pengulangan), kolokasi (penyanding kata), dan ekuivalensi. Tujuan penggunaan aspek-aspek leksikal itu, antara lain, ialah untuk mendapatkan efek intensitas makna, keindahan bahasa, atau kejelasan informasi.

\section{Alat Kohesi Leksikal}

Menurut Indiyastini (2005: 39) berdasarkan perwujudan lingualnya, kohesi dibedakan menjadi dua jenis, yaitu kohesi gramatikal dan kohesi leksikal. Piranti kohesi gramatikal meliputi konjungsi, ellipsis, subtitusi, dan referensi. Piranti kohesi leksikal meliputi repetisi, sinonim, antonim, hiponim, dan kolokasi.

\section{Repetisi}

Repetisi atau pengulangan adalah pemakaian kata yang sama atau hampir sama secara berulang. (Ahmadi, 1990: 184). Pengulangan dibagi menjadi dua yaitu pengulangan utuh dan sebagian. Pengulangan utuh yaitu pengulangan kata atau frasa terjadi secara menyeluruh, sedangkan pengulangan sebagian yaitu pengulangan terjadi pada bagian kata atau frasanya saja. Berikut contoh penggunaan repetisi dalam paragraf:

\section{Sinonim}

Sinonim merupakan salah satu aspek leksikal untuk mendukung kepaduan wacana atau paragraf. Kridalaksana (dalam Indiyastini, 2009: 76) mengatakan bahwa sinonim adalah satuan lingual yang maknanya mirip atau kurang lebih sama dengan satuan lingual lain. Kesamaan itu berlaku bagi kata, kelompok kata, atau kalimat walaupun umumnya yang dianggap sinonim hanyalah kata-kata saja. Unsurunsur yang bersinonim dalam wacana itu dapat berupa sinonim murni dan sinonim mirip. Sinonim murni adalah sinonim yang makna antarunsurnya tidak sama betul. Berkaitan dengan itu, Verhaar (dalam Indiyastini, 2009: 76) juga mengemukakan bahwa lazimnya hubungan antar sinonim itu akan menyisakan nuansa, tetapi maknanya boleh disebut "kurang lebih sama". Di dalam wacana atau paragraf, sinonim berfungsi untuk menjalin hubungan makna yang sepadan antara satuan lingual tertentu dengan satuan lingual lain.

\section{Antonim}

Keantoniman merupakan salah satu jenis kohesi leksikal. Kepaduan paragraf diwujudkan dengan bentuk keantoniman. Antonim yang menurut Kridalaksana (dalam Indiyastini, 2009: 81) adalah oposisi makna dalam pasangan leksikal yang dapat dijenjangkan. Dengan kata lain, antonim tersebut dapat diartikan sebagai nama lain untuk benda atau hal yang lain, (yang demikian dapat diartikan pula sebagai satuan lingual yang maknanya berlawanan dengan satuan lingual yang lain).

\section{Hiponim}

Hiponim adalah hubungan yang terjadi antara konstituen yang bermakna umum dan konstituen yang bermakna khusus. Satuan leksikal yang bermakna umum disebut superordinat, sedangkan 
satuan leksikal yang bermakna khusus disebut hiponim. Hal ini dapat diartikan pula sebagai satuan bahasa (frasa, klausa, kalimat) yang maknanya dianggap merupakan bagian dari makna satuan lingual yang lain. Satuan lingual yang mencakupi beberapa satuan lingual yang berhiponim itu disebut "hipernim" atau "superordinat" Sumarlam (dalam Indiyastini, 2009: 83).

\section{Kolokasi}

Kolokasi juga merupakan salah satu alat kohesi leksikal dalam wacana. Kolokasi adalah relasi makna leksikal antara suatu unsur dan unsur yang lain. Dalam hal ini terdapat kesamaan asosiasi atau kemungkinan adanya beberapa kata dalam lingkungan yang sama dalam suatu wacana Halliday dan Harsana (dalam Indiyastini, 2009: 87). yang mengatakan bahwa kolokasi adalah asosiasi tetap kata dengan kata lain yang berdampingan dalam kalimat. Senada dengan pendapat di atas, Sumarlam (dalam Indiyastini, 2009: 87) juga mengatakan bahwa kolokasi atau sanding kata adalah asosiasi tertentu dalam menggunakan pilihan kata yang cenderung digunakan secara berdampingan.

Kata-kata yang berkolokasi adalah kata-kata yang cenderung dipakai dalam suatu domain tertentu. Dicontohkan bahwa dalam domain pendidikan akan digunakan kata-kata yang berkaitan dengan masalah pendidikan dan orang-orang yang terlibat di dalamnya. Demikian pula, dalam domain pasar akan digunakan kata-kata yang berkaitan dengan masalah pasar dan partisipan yang berperan di dalam kegiatan tersebut. Misalnya kata-kata guru, murid, sekolah, buku, pelajaran merupakan katakata yang dipakai dalam domain pendidikan; kata-kata penjual, pembeli, kios, toko, laba, rugi dipakai dalam domain pasar.

\section{Ekuivalensi}

Ekuivalensi merupakan makna yang memiliki kedekatan atau memiliki tingkatan sebanding. Sementara, semantik adalah ilmu tentang makna kata dan kalimat atau pengetahuan mengenai seluk beluk dan pergeseran makna. Jadi dapat disimpulkan, ekuivalensi semantik adalah kajian semantik yang memiliki hubungan kedekatan, sebanding, dan kekerabatan.

Asumsi awal mengenai ekuivalensi konseptual atau sinonim dapat diperlihatkan secara langsung melalui sistem penggambaran semantik. Perlu disusun kaidah khusus untuk menjelaskan ekuivalensi semantik untuk penggambaran semantik. Kaidah ini bersifat arbitrer yang diimprovisasi agar para ahli semantik dapat terlepas dari problem analitis dalam hubungan semantik kekerabatan. Dalam pembahasan ini disampaikan sejumlah kaidah implikasi dan kemudian memikirkan apakah kaidah ini memberikan fakta untuk tingkat 'semantik dalam'.

\section{Cerita Pendek}

Cerita pendek adalah karangan pendek yang menceritakan seorang tokoh dengan sebuah masalah beserta penyelesaiannya. Jumlah kata dalam cerita pendek kurang dari 10 ribu kata, kemudian kata-katanya mudah dimengerti sehingga, tokohnya sedikit dan penokohannya cenderung sederhana.

Menurut Shousetsu (dalam Pujiono, 2006 : 6) mengatakan bahwa cerpen timbul sebagai suatu yang menggambarkan tentang kejadian sehari-hari dimasyarakat, meskipun kejadian yang tidak nyata, tetapi itu merupakan sesuatu yang dapat dipahami dengan prinsip yang sama dalam kehidupan sehari-hari. Di dalam cerpen itu lebih menitikberatkan kepada tokoh manusia (peran) di dalam karangannya dari pada terjadinya dan secara keseluruhan 
mengambil bentuk yang dikatakan (disebut) dengan ciptaan dunia berdasarkan kepada perbedaan individual.

Cerita Pendek (cerpen), yakni cerita yang menurut wujudnya berbentuk pendek. Ukuran panjang pendeknya suatu cerita memamng relatif. Namun, pada umumnya cerita pendek merupakan cerita yang habis dibaca sekitar sepuluh menit atau setengah jam. Jumlah katanya sekitar 500-5.000 kata. Cerita pendek pada umumnya bertema sederhana. Halnya dengan jumlah tokohnya yang terbatas. Jalan ceritanya sederhana latarnya meliputi ruang lingkup yang terbatas. Kosasih (2014:111)

Dari pendapat di atas, dapat diketahui bahwa teks cerita pendek merupakan suatu yang meng-gambarkan tentang kejadian sehari-hari di masyarakat, meskipun kejadian yang tidak nyata, tetapi itu merupakan sesuatu yang dapat dipahami dengan prinsip yang sama dan sederhana dalam menceritakan kehidupan sehari-hari dimana lebih menitikberatkan kepada tokoh manusia yang terbatas dalam karangan dari pada kejadiannya sehingga cerita pendek dapat dihasilkan dengan cerita yang pendek namun jelas alur ceritanya.

\section{METODE PENELITIAN}

Metode yang digunakan dalam penelitian ini, yaitu metode deskriptif kualitatif. Metode penelitian tersebut merupakan metode yang menitik beratkan pengumpulan datanya pada kata-kata atau kalimat. Menurut Sugiyono (2015:14-15) penelitian kualitatif merupakan metode yang dilakukan secara natural atau alamiah. Bukan hanya proses penelitiannya saja yang bersifat alamiah. Objek yang akan diteliti pun harus bersifat alamiah. Objek yang dipilih yaitu objek yang natural, berkembang apa adanya (tidak ada proses manipulasi) dan dinamika yang dimiliki objek tidak akan terpengaruh oleh kehadiran peneliti.

Pada pelaksanaan penelitian, data cerpen karya siswa yang terkumpul akan dideskripsikan secara intens dan spesifik tentang penggunaan alat kohesi oleh peneliti. Alat kohesi leksikal tersebut terdiri atas sinonim (makna mirip), antonim (lawan kata), hiponim (hubungan bagian atau isi), repetisi (pengulangan), kolokasi (penyanding kata), dan ekuivalensi. Tujuan penggunaan aspek-aspek leksikal itu, antara lain, ialah untuk mendapatkan efek intensitas makna, keindahan bahasa, atau kejelasan informasi. Dengan demikian, penelitian ini menggunakan pendekatan analisis deskripsi karena hasil dari penelitian ini berupa data deskriptif.

Keabsahan data dalam penelitian ini menggunakan triangulasi. Arikunto (2014:25) menjelaskan bahwa sebenarnya prinsip triangulasi ini tidak hanya ada dalam penelitian kualitatif, tetapi dalam semua penelitian pun penting adanya prinsip triangulasi. Kemudian pada triangulasi dengan metode terdapat dua stategi, yaitu pengecekan derajat kepercayaan penemuan hasil penelitian beberapa teknik pengumpulan data dan pengecekan derajat kepercayaan beberapa sumber data dengan metode yang sama (Patton, 1987:329).

Pengecekan keabsahan data dilakukan peneliti agar terhindar dari kesalahan data dalam proses penelitian. Seperti yang telah disebutkan sebelumnya, pengecekan data dapat dilakukan dengan teknik triangulasi. Triangulasi diartikan sebagai teknik pengecekan data yang bersifat menggabungkan hasil penelitian yang telah dicek keabsahan datanya oleh triangulator. Adapun tabel triangulator sebagai berikut. Dari pendapat di atas dapat disimpulkan bahwa penelitian kualitatif merupakan metode penelitian yang baik 
proses atau pun objeknya bersifat alami atau apa adanya. Penelitian deskriptif kualitatif menuntut penelitinya memiliki wawasan yang luas dan bekal teoretis yang cukup. Di sisi lain, dikenal pula istilah triangulasi, yaitu proses pengecekan data yang dilakukan oleh orang lain, biasanya berjumlah tiga orang. Orang yang akan melakukan pengecekan data yang dikumpulkan oleh peneliti disebut sebagai triangulator.

\section{Data dan Sumber Data}

1. Data

Data penelitian ini berupa kutipankutipan kalimat yang menunjukkan adanya alat kohesi leksikal. Kutipan kalimat diambil pada teks cerita pendek siswa kelas XI SMA Negeri 4 Bogor.

2. Sumber Data

Sumber data penelitian ini yaitu teks cerita pendek siswa kelas XI SMA Negeri 4 Bogor

\section{Teknik Pengumpulan Data}

Sebelum peneliti melakukan analisis, maka terlebih dahulu peneliti melakukan beberapa langkah persiapan yaitu sebagai berikut:

1. Mengumpulkan data utama, berupa teks cerita pendek siswa kelas XI SMA Negeri 4 Bogor.

2. Menelaah teks cerita pendek secara keseluruhan, untuk memperoleh data tentang alat kohesi leksikal yang terdapat pada teks cerita pendek, lalu dianalisis.

3. Mengelompokkan data sesuai alat kohesi leksikal yang berupa repetisi, sinonim, antonim, hiponim, kolokasi, dan ekuivalensi yang terdapat pada teks cerita pendek dan memasukkannya ke dalam kartu data berdasarkan alat kohesi tersebut.
4. Memasukkan hasil temuan data ke dalam tabel.

5. Menganalisis alat kohesi leksikal yang terdapat pada teks cerita pendek.

\section{HASIL PENELITIAN DAN PEMBAHASAN \\ Hasil penelitian}

Hasil penelitian ini menunjukkan bahwa dalam 25 cerpen siswa yang dianalisis ditemukan penggunaan kohesi leksikal sebanyak 140 temuan data. Temuan tersebut mencakup jenis alat kohesi leksikal berupa repetisi sebanyak 36 data (26\%). Alat kohesi leksikal tersebut ditemukan pada pengulangan kata tak utuh pada kata ganti orang, kata utuh pada kata ganti orang, dan kata utuh pada kata keterangan waktu. Seperti; kata cewek itu merujuk pada kata Diana. Kata utuh pada kata ganti orang ditemukan repetisi seperti; kata ayah pada kalimat kedua merupakan rujukan pada kata ayah kalimat pertama, dan kata utuh pada kata ganti keterangan waktu seperti; kata hari ini yang merupakan rujukan dari kata hari ini pada kalimat sebelumnya. Reptitsi ini digunakan untuk menyatakan penegasan gagasan atau keindahan bacaan. Kemudian penggunaan sinonim juga banyak digunakan dalam cerpen siswa sebanyak 14 (10\%). Seperti, kata jujur dan kata terus terang. Sinonim digunakan untuk menghindari terjadinya pengulangan kata-kata yang sama dalam penginderaan sebuah obyek yang dapat menyebabkan teks deskripsi tersebut menjadi tidak menarik. Selanjutnya, penggunaan antonim sebanyak 24 (17\%). seperti; kata menanyakan dan kata menjawab. Antonim digunakan untuk membandingkan kata/lawan dari kata satu dengan kata yang berlawanan. Lalu penggunaan hiponim sebanyak 10 (7\%). Seperti, kata SMA dan Kata Kuliah yang 
memiliki makna sebagai ranah umum pendidikan pada alat kohesi leksikal hiponim. Hiponim digunakan untuk menunjukkan relasi antara kata di setiap kalimatnya. Berikutnya penggunaan kolokasi sebanyak 24 (17\%). Seperti, kata gugup, kata jatuh hati, dan kata tersenyumsenyum yang merupakan alat kohesi leksikal berupa kolokasi. Alat kohesi tersebut digunakan untuk menyatakan keterkaitan makna pada kata dalam setiap kalimat. Terakhir, dalam cerpen siswa juga banyak ditemukan penggunaan ekuivalensi dengan total temuan sebanyak 32 (23\%). Penggunaan ekuivalensi dapat diketahui dengan mencermati penggunaan makna yang sangat berdekatan karena penggunaan kata dasar yang sama seperti; kata perasaan dan kata merasa yang berasal dari kata rasa.

Berdasarkan hasil analisis pada teks cerita pendek siswa terdapat 140 data penggunaan alat kohesi leksikal. Hasil analisis menunjukkan bahwa penggunaan alat kohesi leksikal terbanyak, yaitu penggunaan repetisi, yaitu sebanyak 36 data. Kemudian yang jumlahnya sedang, yaitu ekuivalensi sebanyak 32 data. Penggunaan alat kohesi yang paling sedikit digunakan adalah alat kohesi leksikal berupa hiponim dengan jumlah temuan data sebanyak sepuluh data.

Berkenaan dengan hasil analisis penggunaan alat kohesi leksikal yang meliputi repetisi, sinonim, antonim, hiponim, kolokasi, dan ekuivalensi. Dapat disimpulkan bahwa penggunaan alat kohesi leksikal yang paling dominan pada cerita pendek siswa kelas XI SMA Negeri 4 Bogor terdapat pada penggunaan alat kohesi leksikal berupa repetisi dengan temuan data 36 kutipan dengan persentase $26 \%$.

Berikut ini tabel rekapitulasi analisis kohesi leksikal.
Grafik 1

Rekapitulasi Analisis Alat Kohesi Leksikal

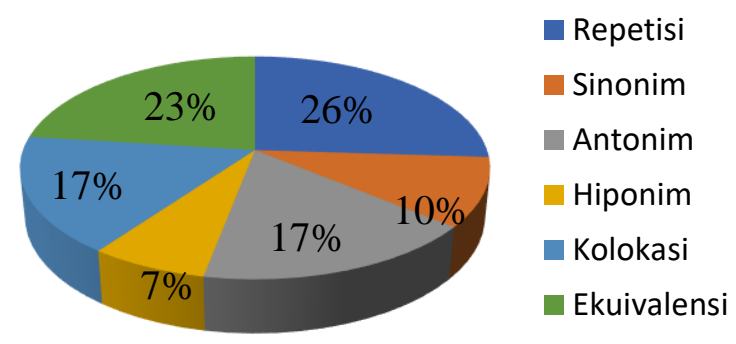

\section{SIMPULAN DAN SARAN}

\section{Simpulan}

Berdasarkan hasil analisis dan pembahasan mengenai penggunaan alat kohesi leksikal pada teks cerita pendek siswa kelas XI SMA Negeri 4 Bogor dapat disimpulkan bahwa ditemukan enam jenis alat, yang pertama adalah alat kohesi leksikal repetisi ditemukan pada pengulangan kata tak utuh pada kata ganti orang, kata utuh pada kata ganti orang, dan kata utuh pada kata keterangan waktu. Kata tak utuh pada kata ganti orang yang ditemukan seperti; kata cewek itu merujuk pada kata Diana. Kata utuh pada kata ganti orang ditemukan repetisi seperti; kata ayah pada kalimat kedua merupakan rujukan pada kata ayah kalimat pertama, dan kata utuh pada kata ganti keterangan waktu seperti; kata hari ini yang merupakan rujukan dari kata hari ini pada kalimat sebelumnya. Kedua, kata jujur dan kata terus terang yang termasuk alat kohesi leksikal sinonim. Ketiga, alat kohesi leksikal antonim seperti; kata menanyakan dan kata menjawab. Keempat, kata SMA dan Kata Kuliah yang memiliki makna sebagai ranah umum pendidikan pada alat kohesi leksikal hiponim. Kelima, kata gugup, kata jatuh hati, dan kata tersenyumsenyum yang merupakan alat kohesi leksikal kolokasi, dan keenam adalah 
ekuivalensi dimana penggunaan makna yang sangat berdekatan karena penggunaan kata dasar yang sama seperti; kata perasaan dan kata merasa yang berasal dari kata rasa. Oleh karena itu, enam alat kohesi leksikal sangat dibutuhkan dalam penulisan sebuah paragrap agar pembaca tidak bosan serta dapat mengikuti irama isi dari paragrap tersebut.

Hasil analisis menunjukkan bahwa penggunaan alat kohesi leksikal terbanyak yaitu penggunaan repetisi sebanyak 36 data yang dipresentasekan menjadi $26 \%$. Jadi, dengan mencermati hasil analisis penggunaan alat kohesi leksikal pada teks cerita pendek siswa tersebut dapat diketahui bahwa yang paling banyak digunakan oleh siswa dalam membuat cerpen adalah alat kohesi leksikal berupa repetisi. Hal ini dimungkinkan karena pengetahuan siswa terhadap penggunaan alat kohesi leksikal dalam membuat cerpen masih terbatas. Hanya penggunaan gaya bahasa pengulangan saja yang rata-rata mereka ketahui. Selain itu, hal tersebut dapat disebabkan karena kurangnya daya baca siswa sehingga perbendaharaan kosakata di dalam pemikirannya juga terbatas.

\section{Saran}

Saran yang harus disampaikan setelah melakukan penelitian berupa analisis penggunaan kohesi leksikal pada teks cerita pendek siswa kelas XI SMA Negeri 4 Bogor. Saran yang harus disampaikan peneliti sebagai berikut.

1. Guru sebaiknya mengenalkan lebih luas lagi mengenai makna kata pada kalimat, terutama pada teks cerita pendek dengan menggunakan metode dan teknik pembelajaran yang menarik sehingga siswa akan antusias dalam belajar khususnya penggunaan alat kohesi leksikal pada teks cerita pendek.

2. Siswa sebaiknya lebih memperhatikan guru ketika menjelaskan mengenai makna kata di dalam kelas, sehingga saat siswa diminta untuk membuat teks cerita pendek, siswa dapat membuatnya dengan meggunakan makna kata yang tepat.

\section{DAFTAR PUSTAKA}

Ahmadi, Muhsin. 1990. Dasar-dasar komposisi. Malang: YA3.

Amertawengrum, Indiyah Prana. 2010. "Teks dan Intertekstualitas". Jurnal Magistra No. 73 Th. XXII September 2010.

Aminudin. 2010. Kreatif Menulis Puisi dan Cerita Pendek. Tanggerang: Citralab.

Arifin, E. Zaenal, dkk. 2014. Morfologi Bahasa Indonesia untuk Program Studi Pendidikan Bahasa dan Sastra. Tangerang: Pustaka Mandiri.

Arifin, E. Zaenal, dkk. 2015. Wacana Transaksional dan Interaksional dalam Bahasa Indonesia. Tangerang: Pustaka Mandiri.

Badan Pengembangan dan Pembinaan Bahasa Kementrian Pendidikan dan Kebudayaan. 2016. Pedoman Umum Ejaan Bahasa Indonesia. Jakarta.

Indiyastini, T. 2009. Kohesi dan Koherensi Paragraf dalam Bahasa Jawa. Yogyakarta: Balai Bahasa Yogyakarta. Kosasih, E. 2014. Jenis-jenis Teks. Bandung: YramaWidya.

Kurhartanti, Yuwono, dkk. 2005. Pesona Bahasa Langkah Awal Memahami Linguistik. Jakarta: PT Gramedia.

Mulyana. 2005. Kajian Wacana: Teori, Metode dan Aplikasi Prinsip-Prinsip Analisis Wacana. Yogyakarta: Tiara Wacana.

M.S. Mahsum. 2014. Teks dalam Pembelajaran Bahasa Indonesia. Jakarta: PT Raja Grafindo Persada. 
Parera, JD. 1993. Leksikon Istilah

Pembelajaran Bahasa. Jakarta:

Gramedia.

Priyatni, Endahtri. 2015. Desain Pembelajaran Bahasa Indonesia dalam Kurikulum 2013. Jakarta: Bumi Aksara.

Rokhmansyah, Alfian. 2014. Studi dan Pengkajian Sastra: Perkenalan Awal Terhadap Ilmu Sastra. Yogyakarta: Graha Ilmu.

Suryadi Adi. 2016. "Analisis Kohesi Paragraf Pada Cerita Pendek Pak Molla Karya James Danandjaja" dalam Lingua: Jurnal Cerita Pendek. Jamuari 2017.

Supardo, Susilo. 1998. Bahasa Indonesia dalam Konteks. Jakarta: Depdikbud, Dirjen Dikti, L2LPTK. Suwarna, Dadan. 2016. Kreatif dan Cerdas
Berbahasa Indonesia. Depok: Khalifah Mediatama.

Suladi. 2000. Kohesi dalam Media Massa Cetak Bahasa Indonesia. Jakarta: Pusat Bahasa Departemen Pendidikan Nasional.

Sumarlam. 2003. Teori dan Praktik Analisis Wacana. Surakarta: Pustaka Cakra.

Tarigan, H Guntur. 2013. Pengajaran Gaya Bahasa. Bandung: Angkasa.

Tarigan, H Guntur. 1988. Pengajaran Pemerolehan Bahasa. Jakarta: Departemen Pendidikan dan Kebudayaan.

Tarigan, H Guntur. 2009. Pengajaran Wacana. Bandung: Angkasa.

Zaimar, O.K.S dan Ayu Basoeki Harahap. 2015. Teori Wacana. Jakarta: Penaku. 